\title{
Reversible Inhibitory Effects of Apo-B-Carrying Lipoproteins on Acid Lipase Activity of Mononuclear Leukocytes from Cholesterol-Fed Rabbits
}

\author{
Fusako MaEhIRA, ${ }^{1, *}$ Ikuko MiyAGI, ${ }^{1}$ Junko NAGAmine, ${ }^{1}$ \\ and Shinzoh KOHNO ${ }^{2}$ \\ ${ }^{1}$ Department of Biochemistry for Health Science, ${ }^{2}$ Second Department of Adult Health, \\ School of Health Sciences, Faculty of Medicine, University of the Ryukyus, \\ Nishihara, Okinawa 903-01, Japan
}

(Received June 6, 1990)

\begin{abstract}
Summary Acid lipase (AL) activity of mixed mononuclear leukocytes from cholesterol-fed rabbits exhibited reduced values when compared with that of normolipidemic rabbits. The observed suppression of the AL activity was reversed commensurate with a fall in the plasma concentrations of cholesterol and lipid peroxides (LPO) after the rabbits were returned to a basal diet. The AL activity was negatively correlated with both plasma cholesterol and LPO levels in rabbits. This reversible inhibition was caused by apo-B-carrying lipoproteins from the hypercholesterolemic rabbits, and protective effects were produced by preincubation of lipoproteins with anti apo-B serum. The increase in plasma LPO in the hypercholesterolemic rabbits suggests that the observed reversible inhibition of the AL activity might be due to an increase in free radicals produced in the process of lipid peroxidation in the hypercholesterolemic state. The current findings also suggest that, through the combined effects of suppression of lysosomal hydrolysis and stimulation of microsomal synthesis of esterified cholesterol, $\beta$-migrating very low density lipoprotein in cholesterol-fed rabbits accelerates hypercholesterolemia and causes accumulation of esterified cholesterol in cells.
\end{abstract}

Key Words: acid lipase, apo-B-carrying lipoproteins, lipid peroxides, mononuclear leukocytes, hypercholesterolemic rabbits

Acidic cholesteryl ester hydrolase (EC 3.1.1.13) is located on the lysosomal membrane and hydrolyzes exogenous low density lipoprotein (LDL)-associated

*To whom correspondence should be addressed. 
cholesterol esters (E-CHO) that have been internalized through receptor-mediated endocytosis [1]. A hereditary deficiency of this enzyme is known as Wolman's disease, and a massive accumulation of $\mathrm{E}-\mathrm{CHO}$ is seen in various organs of affected patients [2]. In both the LDL-receptor pathway and the $\beta$-VLDL receptor pathway of E-CHO metabolism, the lysosomal degradation of lipoproteinassociated $\mathrm{E}-\mathrm{CHO}$ is a prerequisite for the intracellular cholesterol pool to regulate its synthesis and for E-CHO formation in cells [3, 4]. Although intensive studies on the series of cellular events in the receptor-mediated pathway of the E-CHO-rich lipoprotein metabolism have been done, the regulatory mechanism of lysosomal acid lipase (AL) is not yet known. In peripheral blood, lysosomal acid lipase activity has been found in lymphocytes bearing the LDL receptor [5] and in monocytes having both the LDL receptor and the $\beta$-migrating very low density lipoprotein $(\beta$-VLDL) receptor $[6,7]$.

In the present study, the reversible inhibition of acid lipase by its physiological substrate, LDL or $\beta$-VLDL, was demonstrated by use of mixed mononuclear leukocytes from hypercholesterolemic rabbits. These cells consisted of lymphocytes and monocytes and thus represented two pathways of LDL metabolism.

\section{MATERIALS AND METHODS}

Materials. Cholesteryl $\left[1-{ }^{14} \mathrm{C}\right]$ oleate $(57.0 \mathrm{mCi} / \mathrm{mmol})$, cholesteryl $\left[1-{ }^{14} \mathrm{C}\right]-$ linoleate $(59.0 \mathrm{mCi} / \mathrm{mmol})$, and $\left[9,10-{ }^{3} \mathrm{H}(\mathrm{N})\right]$ oleic acid were obtained from NEN Research Products (Boston, MA). Unlabelled esterified cholesterols came from Sigma (St. Louis, MO); purified Triton X-100, from Pierce (Rockford, IL); Lyphogel, from Gelman Instruments (Ann Arbor, MI); and Cellogel, from Chemetron (Milan).

Animals. Japanese white rabbits, weighing 2.4-3.0 kg were fed a commercial rabbit ration (RC4; Oriental Yeast Co., Tokyo) ad libitum according to the diet regimens and time schedules indicated in Table 1 . BALB/c mice were used for production of antiserum against LDL isolated from a hypercholesterolemic rabbit.

Preparation of samples. Mononuclear leukocytes (MNL) were isolated from heparinized blood freshly drawn from rabbits after $14 \mathrm{~h}$ of fasting, according to the method described by Böyum [8]. The cell pellets were disrupted by homogenization in substrate-dissolving buffer containing $0.1 \%(\mathrm{w} / \mathrm{v})$ Triton X-100. The supernatant, obtained by centrifugation at $12,000 \mathrm{rpm}$ for $20 \mathrm{~min}$, was used for the enzyme source.

Assay of AL activity. A $10 \mathrm{~mm}$ substrate suspension of cholesteryl $\left[1-{ }^{14} \mathrm{C}\right]-$ oleate or cholesteryl $\left[1-{ }^{14} \mathrm{C}\right]$ linoleate having a final specific activity of about 1,000 $\mathrm{dpm} / \mathrm{nmol}$ was prepared in $0.1 \mathrm{M}$ acetate buffer $(\mathrm{pH} 4.5$ ) containing $1 \mathrm{~mm} \beta$ mercaptoethanol, EDTA, and $0.1 \%(\mathrm{w} / \mathrm{v})$ Triton X-100 [9]. The reaction mixture consisted of $30 \mu \mathrm{l}$ of enzyme (containing $10-50 \mu \mathrm{g}$ of protein) and $30 \mu \mathrm{l}$ of substrate. After a $2 \mathrm{~h}$-incubation at $37^{\circ} \mathrm{C}$, the reaction was stopped, and the fatty acid was extracted by the solvent system according to Belfrage and Vaughan [10]. 
Table 1. Acid lipase activity of mononuclear leukocytes from rabbits on a cholesterol diet.

\begin{tabular}{|c|c|c|c|c|c|c|c|}
\hline Rabbits & Diet & $\begin{array}{l}\text { Period } \\
\text { (month) }\end{array}$ & $\begin{array}{l}\text { AL activity } \\
\text { (units/mg) }\end{array}$ & $\begin{array}{l}\text { T-CHO } \\
(\mathrm{mg} / \mathrm{dl})\end{array}$ & $\begin{array}{l}\text { E-CHO } \\
(\mathrm{mg} / \mathrm{dl})\end{array}$ & $\begin{array}{c}\mathrm{TG} \\
(\mathrm{mg} / \mathrm{dl})\end{array}$ & $\begin{array}{c}\text { TBA } \\
(\mathrm{nmol} / \mathrm{ml})\end{array}$ \\
\hline B-1 (ন) & B & 1 & 3.31 & 34 & $14(41 \%)$ & 54 & 1.80 \\
\hline B-2 ( & & 1 & 2.33 & 41 & $16(39 \%)$ & 29 & 1.65 \\
\hline CP-1 ( ( ত) & $\mathrm{CP}$ & 1 & 1.42 & 150 & 77 (51\%) & 37 & 1.83 \\
\hline CP-2 (অ) & & 1 & 0.76 & 746 & $716(96 \%)$ & 38 & 1.90 \\
\hline C-1 ( & $\mathrm{C}$ & 1 & 2.02 & 962 & $922(96 \%)$ & 103 & 1.98 \\
\hline C-2 (のフ) & & 1 & 0.55 & 1,946 & $1,882(97 \%)$ & 149 & 2.20 \\
\hline \multirow[t]{2}{*}{ C-3 (우*) } & $\mathrm{C}$ & 5 & 1.30 & 720 & $688(96 \%)$ & 138 & 2.02 \\
\hline & $\mathrm{B}^{* *}$ & 1 & 6.30 & 53 & $38(72 \%)$ & 60 & 1.59 \\
\hline \multirow[t]{2}{*}{ C-4 (우) } & $\mathrm{C}$ & 5 & 0.31 & 2,356 & $2,215(94 \%)$ & 357 & 2.43 \\
\hline & $\mathrm{B}^{* *}$ & 1 & 2.80 & 629 & $429(68 \%)$ & 85 & 1.91 \\
\hline \multirow[t]{2}{*}{ C-5 (우) } & $\mathrm{C}$ & 5 & 0.85 & 1,420 & $1,112(73 \%)$ & 75 & 2.15 \\
\hline & $\mathrm{B}^{* *}$ & 1 & 8.30 & 72 & $17(24 \%)$ & 24 & 1.75 \\
\hline \multirow[t]{2}{*}{ C-6 (우) } & $\mathrm{C}$ & 5 & 1.25 & 818 & 782 (96\%) & 77 & 2.07 \\
\hline & $\mathrm{B}^{* *}$ & 1 & 4.75 & 106 & $68(62 \%)$ & 25 & 1.55 \\
\hline
\end{tabular}

Rabbits were fed a commercial chow for the indicated periods of time according to the following dietary regimens: $\mathrm{B}$, basal diet with $18 \%(\mathrm{w} / \mathrm{w})$ protein; $\mathrm{CP}$, basal diet with $5 \%$ protein plus $1 \%(\mathrm{w} / \mathrm{w})$ cholesterol; C, diet B plus $1 \%$ cholesterol. The E-CHO levels were presented in $\mathrm{mg} / \mathrm{dl}$ and as percent of $\mathrm{T}-\mathrm{CHO}$ (in parentheses). *Oophorectomized, ** rabbits received $\mathrm{B}$ diet for 1 month after having been kept on $\mathrm{C}$ diet for 5 months.

The percent recovery obtained by the extraction procedure was determined by use of $\left[9,10-{ }^{3} \mathrm{H}(\mathrm{N})\right]$ oleic acid. One unit of enzyme activity was defined as that amount of enzyme catalyzing the release of $1 \mathrm{nmol}$ fatty acid per hour. In this assay system, parameters for the enzyme reaction were apparent $K_{\mathrm{m}}=2.2 \mathrm{mM}$, apparent $V_{\max }=$ 10.3 units/mg for cholesteryl oleate and apparent $K_{\mathrm{m}}=2.7$, apparent $V_{\max }=6.8$ for cholesteryl linoleate. In the inhibition study, the substrate was premixed with 10 $\mu 1$ of lipoproteins $(115-374 \mu \mathrm{g} / \mathrm{ml})$ and the reaction was started by addition of a $20-\mu 1$ sample. In the experiment for preventing the inhibitory effect of lipoproteins, $1 \mu 1$ of undiluted or $1 / 10$ diluted antiserum was preincubated with $10 \mu 1$ of lipoproteins for $2 \mathrm{~h}$ at $4^{\circ} \mathrm{C}$, followed by addition of the substrate and the enzyme prepared from MNL of a normolipidemic rabbit. A $0.15 \mathrm{M} \mathrm{NaCl}$ solution containing $1 \mathrm{~mm}$ EDTA substituted for lipoproteins in the control assay.

Preparation of lipoproteins. Freshly obtained rabbit plasma collected in $0.1 \%(\mathrm{w} / \mathrm{v})$ EDTA after $14 \mathrm{~h}$ of fasting was fractionated by discontinuous density gradient ultracentrifugation [11] at $4^{\circ} \mathrm{C}, 40,000 \mathrm{rpm}$ for $48 \mathrm{~h}$. After dialysis against $1 \mathrm{mM}$ EDTA in $0.15 \mathrm{M} \mathrm{NaCl}$, the fractions were concentrated by use of Lyphogel to achieve a protein content of $1-8 \mathrm{mg} / \mathrm{ml}$. The separation of the fractions was confirmed by lipoprotein electrophoresis on Cellogel.

Preparation of anti rabbit apo-B serum. For production of antiserum, 100 $\mu \mathrm{g}$ LDL obtained from a hypercholesterolemic rabbit was mixed with an equal volume of complete Freund's adjuvant and injected intraperitoneally into mice as previously described [13]. The production of antibody was examined by double immunodiffusion [14] on $1.2 \%(\mathrm{w} / \mathrm{v})$ agarose gel against fractionated lipoproteins.

Vol. 9, No. 2, 1990 
Other methods. Plasma level of lipid peroxides was measured as thiobarbituric acid-reactive substances (TBA) by the method of Yagi [15]. Total cholesterol (T-CHO), free cholesterol (F-CHO), triglyceride (TG), and phospholipids $(\mathrm{PL})$ in rabbit sera and in lipoprotein fractions were assayed manually by use of commercial kits (Wako, Osaka) employing enzymatic procedures. Lipoprotein electrophoresis on $0.85 \%(\mathrm{w} / \mathrm{v}$ ) agarose gels (Ciba.Corning, Palo Alto, CA) was also carried out for rabbit sera. Protein in lipoproteins and in enzyme sources was measured by the Folin-Lowry microanalysis method [16].

\section{RESULTS}

All data were expressed as the mean values of duplicate determinations.

\section{Relationship between AL activity and plasma cholesterol}

As shown in Table 1, when the plasma cholesterol levels increased in rabbits
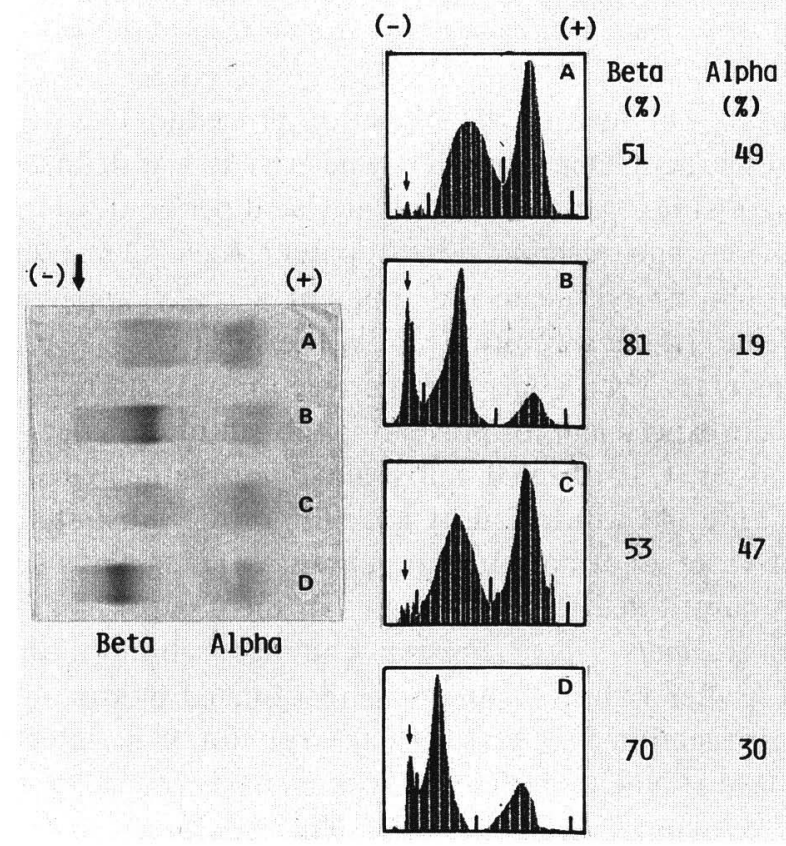

Fig. 1. Agarose gel electrophoretic patterns of lipoproteins during and after cessation of cholesterol diet. The samples from the experiment in Table 1 were subjected to agarose gel electrophoresis at $\mathrm{pH} 8.6$ together with human serum for comparison, followed by staining of the gel with Fat Red 7B. The densitometric scanning patterns are also presented. The arrows indicate the points of sample application. (A) B-1 rabbit on diet B; (B) C-5 rabbit on diet $\mathrm{C}$ for 5 months; (C) C-5 rabbit on diet $\mathrm{B}$ after having been kept on diet $\mathrm{C}$ for 5 months; (D) human serum. 
that had been maintained on a $1 \%(\mathrm{w} / \mathrm{w})$ cholesterol diet for one month $(\mathrm{C}-1,2)$, the corresponding AL activity in MNL decreased. The low protein content of the cholesterol-diet resulted in slower elevation of the plasma cholesterol than the cholesterol-diet with normal protein content, but there was no difference seen in the degree of suppression of the AL activity. The observed relation between the AL activity and plasma cholesterol level was confirmed in another way: the lowered AL activity in the rabbits kept on a cholesterol diet for 5 months rose again when the cholesterol level fell following return of the rabbits (C-3 to C-6 in Table 1) to the basal diet for an additional one month. A parallel alteration of plasma TBA was observed along with the change in plasma cholesterol. A change of lipoprotein patterns of a rabbit during the experiment is also presented in Fig. 1. The increase in plasma cholesterol level was accompanied with an increase in $\beta$-migrating lipoproteins. Linear regression analysis was performed to test possible relationships between the AL activity of MNL on the one hand, and the plasma concentrations of TBA, T-CHO, and TG in Table 1 on the other. The significance of the correlation was tested by the two-sided $t$-test. A most remarkable negative

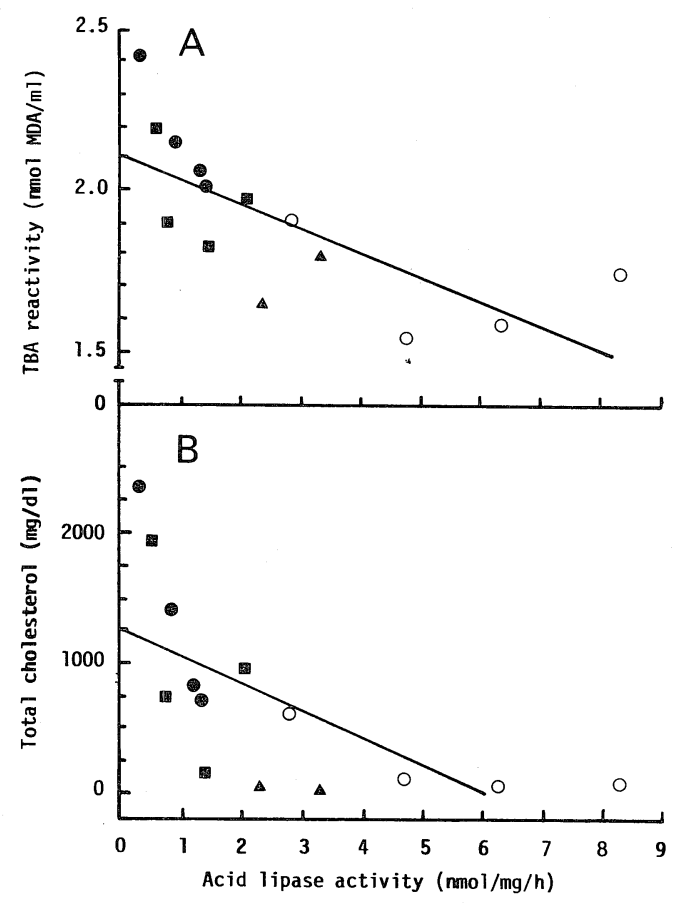

Fig. 2. Correlation between AL activity and plasma TBA (panel A) or plasma cholesterol (panel B) in rabbits. The AL activity of MNL against the plasma levels of TBA and cholesterol of eight cholesterol-fed rabbits (圆, 1 month; 5 months), four rabbits $(\bigcirc)$ on $\mathrm{B}$ diet for 1 month after having been kept on $\mathrm{C}$ diet for 5 months, and two normal rabbits fed diet B ( $\mathbf{\Delta})$ (all data from Table 1) were analyzed for a simple correlation $(r=-0.706, p<0.005$ for panel A; $r=-0.652, p<0.02$ for panel B). 


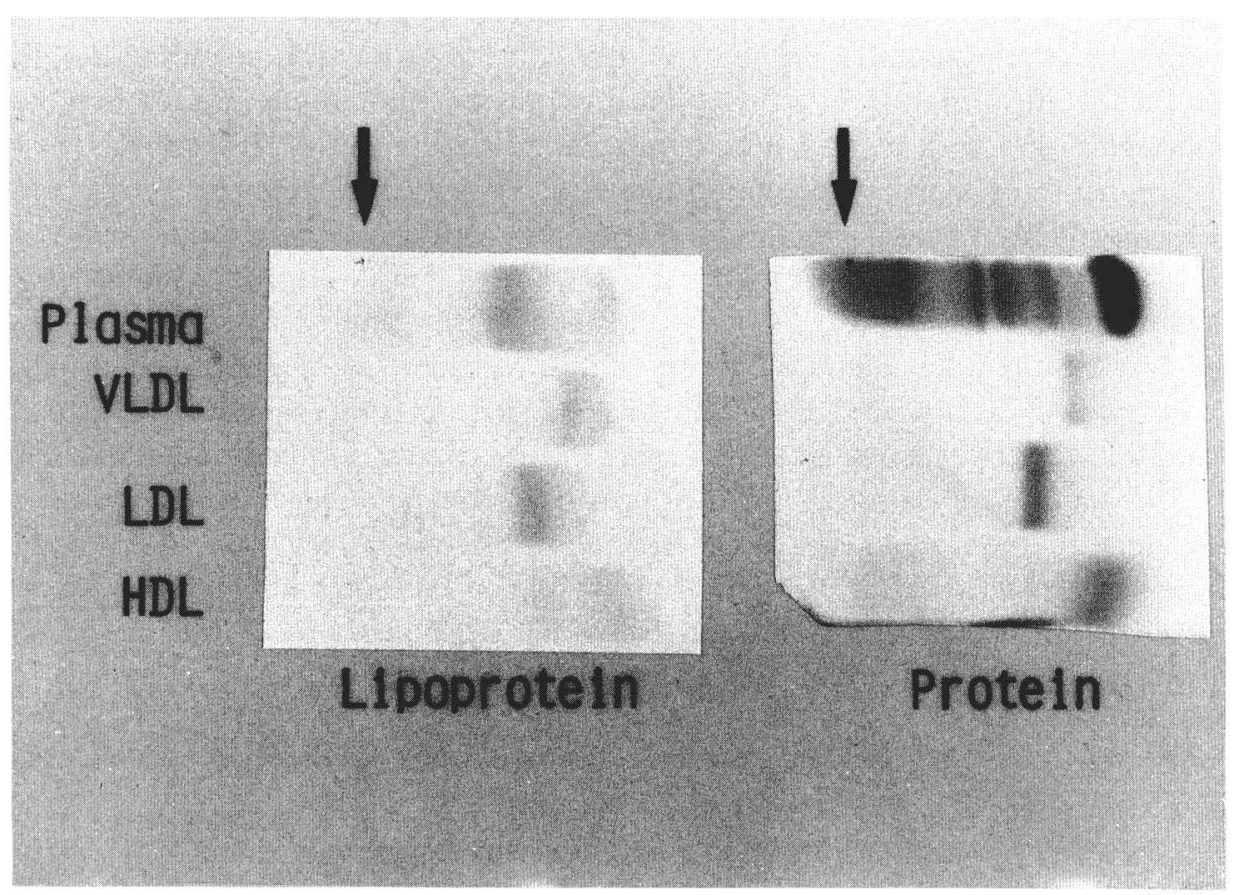

Fig. 3. Cellogel electrophoresis of lipoproteins. Lipoproteins before and after ultracentrifugal fractionation of plasma from a hypercholesterolemic rabbit (C-5) were separated by Cellogel electrophoresis and visualized by staining with ozonization followed by basic fuchsin stain [12] for lipoproteins and with Coomassie brilliant blue G-250 for proteins. Arrows indicate origin.

correlation was found between the AL activity and plasma TBA $(r=-0.706$, $p<0.005)$, and a lesser one between it and plasma T-CHO $(r=-0.652, p<0.02)$ (Fig. 2). There was not a significant correlation between the AL activity and serum TG $(r=-0.465, p>0.05)$, while the plasma TBA level was positively correlated with both T-CHO $(r=0.933, p<0.001)$ and TG $(r=0.805, p<0.001)$.

\section{Effect of lipoproteins on the AL activity}

Since the elevation of plasma cholesterol was mostly due to E-CHO (Table 1) and $\beta$-migrating lipoproteins (Fig. 1), the effects of lipoprotein fractions isolated from normal and hyperlipidemic rabbits (B-1, C-4, C-5 in Table 1) on the AL activity of MNL from a normal rabbit was examined. Although lipoprotein electrophoresis on both agarose gel (Fig. 1) and Cellogel (Fig. 3) exhibited only a $\beta$-migrating lipoprotein and a high-density lipoprotein (HDL) for plasma of hypercholesterolemic rabbits, after the centrifugal fractionations, three fractions, VLDL, LDL, and HDL, were identified on Cellogel electrophoresis (Fig. 3), a procedure that separates VLDL from LDL more distinctly than agarose gel. Since the cholesterol to protein ratios of the hyperlipidemic $d<1.006$ lipoproteins 
Table 2. Characteristics of lipoproteins isolated from normal and hypercholesterolemic rabbits.

\begin{tabular}{llccccc}
\hline Rabbits & $\begin{array}{c}\text { Lipoprotein } \\
\text { fraction }\end{array}$ & $\begin{array}{c}\text { T-CHO } \\
(\mathrm{mg} / \mathrm{dl})\end{array}$ & $\begin{array}{c}\text { F-CHO } \\
(\mathrm{mg} / \mathrm{dl})\end{array}$ & $\begin{array}{c}\text { TG } \\
(\mathrm{mg} / \mathrm{dl})\end{array}$ & $\begin{array}{c}\text { Protein } \\
(\mathrm{mg} / \mathrm{dl})\end{array}$ & $\begin{array}{c}\text { Mass ratio } \\
\text { (T-CHO/Prot.) }\end{array}$ \\
\hline B-1 & Plasma & 35 & 30 & 50 & - & - \\
& $d<1.006$ & 12 & 10 & 29 & 13 & 0.92 \\
& LDL & 171 & 39 & 189 & 125 & 1.37 \\
& HDL & 125 & 37 & 118 & 470 & 0.27 \\
\hline C-4 & Plasma & 641 & 158 & 46 & - & - \\
& d & 3,350 & 574 & 28 & 196 & 17.09 \\
& LDL & 2,786 & 665 & 35 & 760 & 3.67 \\
& HDL & 94 & 28 & 15 & 234 & 0.40 \\
\hline C-5 & Plasma & 609 & 155 & 18 & - & - \\
& $d<1.006$ & 1,354 & 277 & 34 & 95 & 14.25 \\
& LDL & 2,539 & 661 & 31 & 800 & 3.17 \\
& HDL & 76 & 44 & 59 & 92 & 0.83 \\
\hline
\end{tabular}

Rabbits used in the experiment of Table 1, after the return of their plasma cholesterol to the base level in the case of C-4 and C-5, were again maintained on either basal (B-1) or cholesterol (C-4 and C-5) diets for one month, and then their plasma were fractionated as described in Methods.

(VLDL) were approx. 15- to 19-fold greater than this ratio for the normal VLDL (Table 2), the $d<1.006$ lipoprotein of hypercholesterolemic rabbits in the current study can be termed as $\beta$-VLDL similar to the one reported by Mahley et al. [6] although it showed pre- $\beta$ mobility on Cellogel. As shown in Fig. 4, the isolated lipoprotein fractions exhibited an inhibitory effect on the AL activity, and this inhibition seemed to be caused by molecule-to-molecule interactions (D) rather than by their w/v content of E-CHO (A) or other constituents (B, C): E-CHO at concentrations used is unlikely to inhibit the AL activity because it is far less than the substrate concentration $(3.35 \mathrm{mg} / \mathrm{ml})$ in the assay system. In addition, F-CHO, which was present $72 \mu \mathrm{g} / \mathrm{ml}$ at maximum in the assay system of Fig. 4, exhibited an average $35 \%$ inhibition at $387 \mu \mathrm{g} / \mathrm{ml}$ but no inhibition at $77 \mu \mathrm{g} / \mathrm{ml}$. The potency of inhibitory effects was, in order of strength, VLDL, LDL, and HDL. The normal LDL and HDL did not show a similar effect.

\section{Effect of anti apo-B serum on inhibition of AL activity caused by VLDL and $L D L$}

In the inhibitory interaction between lipoproteins and AL at the molecular level, the question as to whether the lipid portion or the protein portion of lipoprotein particles is involved was examined. As summarized in Table 3, anti apo-B serum, which gave a single precipitin line against both VLDL and LDL but not against HDL (Fig. 5), prevented the inhibitory effects caused by VLDL and LDL in proportion to the amount of addition, but there was no such effect seen on HDL. The inhibition observed with the addition of HDL may be due to a 

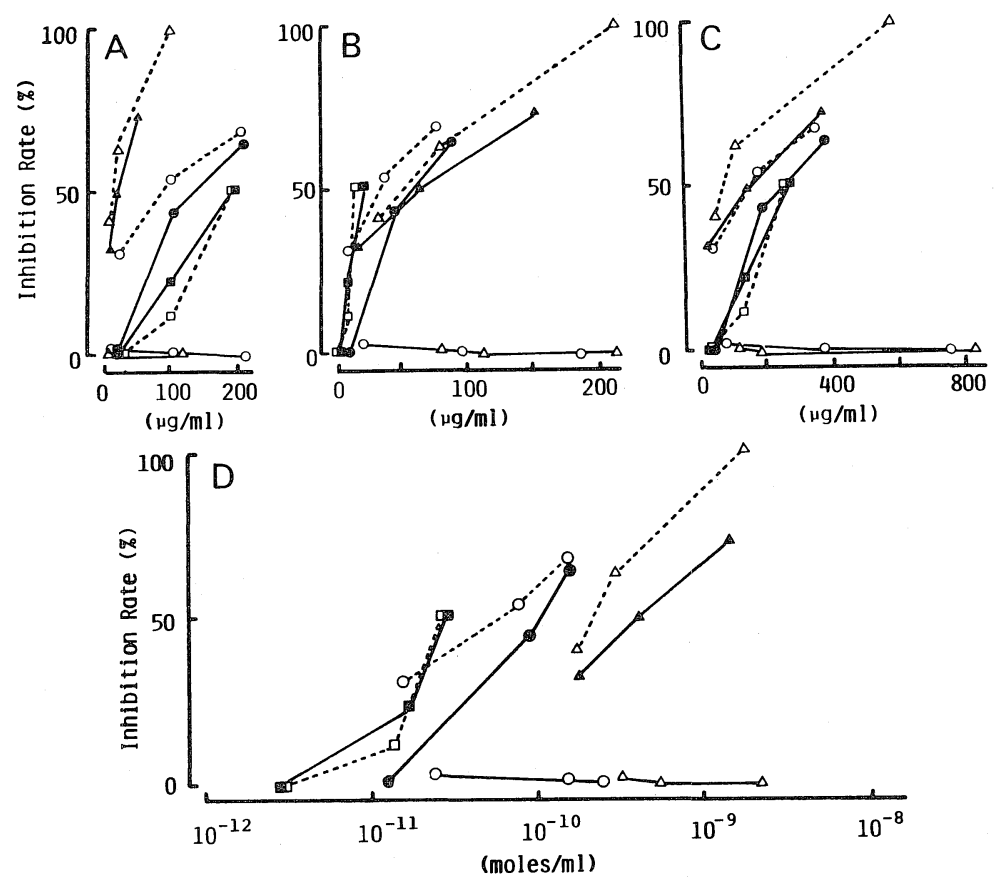

Fig. 4. Effect of lipoproteins on AL activity. With cholesteryl oleate as substrate, the enzyme reaction was carried out in the absence or presence of lipoproteins as described in Methods. The percent inhibition was calculated based on the control activity of 15.5 units/mg. The amount of inhibition is presented with respect to increasing amounts of lipoproteins expressed as the w/v content of E-CHO (A); protein (B); total amount (C), which is a summation of T-CHO, TG, PL, and protein; and number of molecules added (D), which was calculated based on estimated molecular weights of $8.3 \times 10^{6}, 2.2 \times 10^{6}$, and $2.8 \times 10^{5} \mathrm{Da}$ for VLDL, LDL, and HDL, respectively [17]. The symbols of square, circle, and triangle represent VLDL, LDL, and HDL, respectively. The lipoproteins were fractionated from plasma of C-4 (solid lines with closed symbols), C-5 (broken lines with open symbols), and B-1 (solid lines with open symbols) rabbits.

nonspecific interference attributable to a mass-effect with enzyme molecules.

\section{DISCUSSION}

In the hypercholesterolemic state, the appearance of VLDL particles and cholesterol-loaded macrophages in the circulation suggests the participation of monocyte-derived macrophages in the clearance of $\beta$-VLDL from the bloodstream via their $\beta$-VLDL receptor [6]. In cholesterol-fed rabbits, however, the removal of $\beta$-VLDL from the circulation is reduced due to a decrease in the number of and saturation of $\beta$-VLDL receptors on hepatocytes [18]. Consequently, the LDL receptors on hepatocytes, rather than the $\beta$-VLDL receptors on hepatocytes or macrophages, take on the function of removing $\beta$-VLDL from the blood [18]. Taking this evidence into account, we used mixed leukocytes representing both 
Table 3. Prevention of inhibitory effects of lipoproteins on acid lipase by anti apo-B serum.

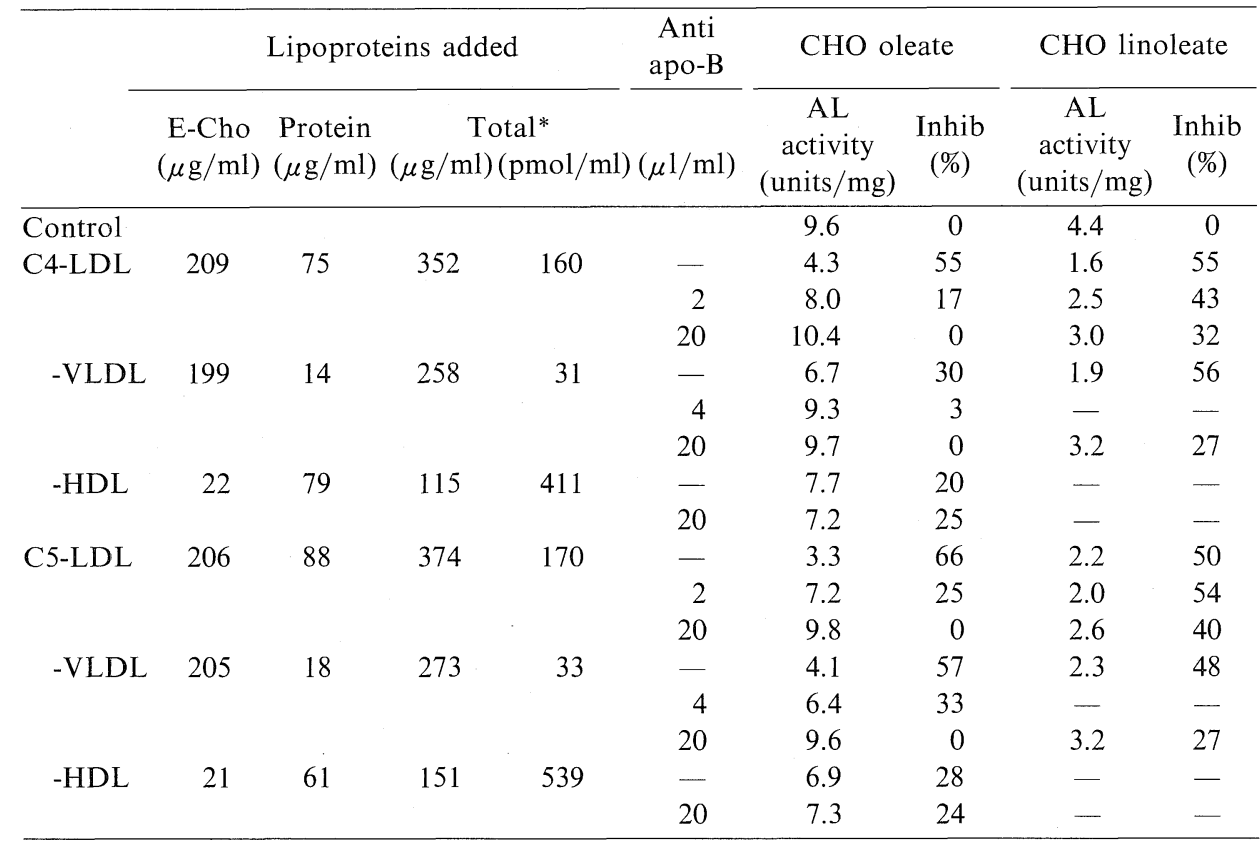

After preincubation of lipoproteins from hypercholesterolemic rabbits in Table 2 with anti apo-B, their effects on the AL activity of MNL isolated from a normolipidemic rabbit were measured by addition of substrate and enzyme as described in Materials and Methods. The inhibition rate was expressed as \% inhibition against the control activity. ${ }^{*}$ Total: T-CHO+ $\mathrm{TG}+\mathrm{PL}+$ Protein, which concentrations were expressed as both $\mu \mathrm{g}$ and pmol per $\mathrm{ml}$ of the assay mixture.

the LDL receptor pathway in lymphocytes and the $\beta$-VLDL receptor pathway in monocytes in the current study. In addition, these peripheral blood cells are constantly exposed to blood constituents, and thus will be under their influence.

As presented in Results, a reversible inhibitory effect of plasma cholesterol on the AL activity was observed (Table 1 and Fig. 2), and this inhibitory interaction was likely caused at the molecular level (Fig. 4) via VLDL and LDL derived from hypercholesterolemic rabbits (Table 3). The LDL fractions from a normolipidemic rabbit did not show such inhibition. Similar effects were reported in the study of E-CHO synthesis in mouse peritoneal macrophages, in which the $d<1.006$ lipoproteins from hypercholesterolemic rabbits stimulated E-CHO formation, whereas those from a normal rabbit did not [6]. Since involvement of sulfhydryl group(s) in the lipolytic activity of AL of human leukocytes [19] as well as of rat liver lysosomes [20] was suggested due to the reduction of the activity by sulfhydryl reagents, AL may be sensitive to oxidation; and thus the observed inhibition of the AL activity might be due to the increase in LPO in apo-B-carrying lipoproteins of the hypercholesterolemic rabbits. Another possi-

Vol. 9, No. 2, 1990 


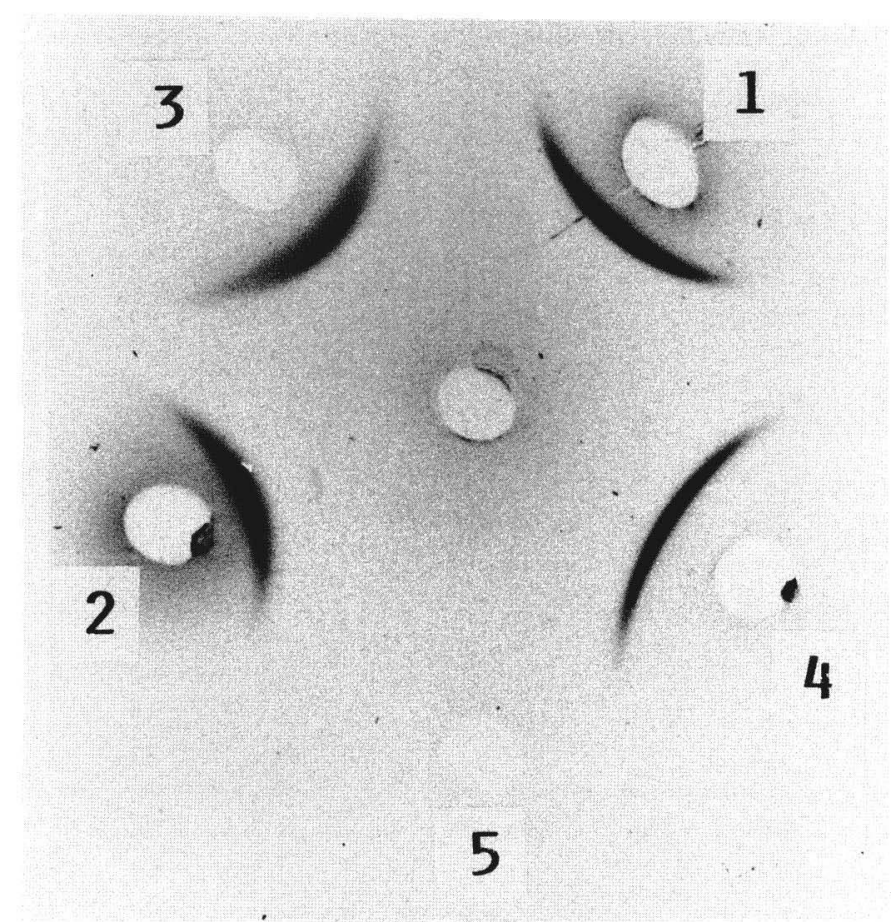

Fig. 5. Double immunodiffusion on $1.2 \%$ agarose gel. Center well contained antiserum (2 $\mu 1)$ against LDL from a hypercholesterolemic rabbit (C-5); well Nos. 1 and 3, VLDL and LDL from rabbit C-5; well Nos. 2 and 4, VLDL and LDL from rabbit C-4; well No. 5, HDL from rabbit C-5. An aliquot of $4 \mu \mathrm{g}$ of lipoproteins was applied to each well.

bility, that the inhibitory effects of LDL and VLDL on the AL activity might be produced via the apoprotein portion as an anti apo-B-inhibitable down regulation, can not be excluded. In this case, the apoprotein portion of LDL and VLDL in hypercholesterolemic rabbits might be altered by free radicals since lipoproteins from normolipidemic rabbits did not exhibit such inhibition. Further study pertaining to the mechanism of inhibition of $\mathrm{AL}$ in the hyperlipidemic condition is in progress. The observed inhibitory effects by apoprotein B on E-CHO hydrolytic activity was more prominent with cholesteryl oleate as substrate than with cholesteryl linoleate (Table 3). There is a report [21] that strongly supports our findings: namely, cholesteryl oleate was predominant among massively accumulated E-CHO in both serum and arterial wall of cholesterol-fed rabbits, and its elimination from the circulation after cessation of the cholesterol diet was slower than that of cholesteryl linoleate and other E-CHO. On the basis of their observations, the authors suggested that both cholesteryl oleate hydrolytic enzymes and its synthetic enzymes are affected in the hypercholesterolemic state.

In cholesterol-fed animals of a variety of species including rabbits, hyper- 
cholesterolemia and E-CHO accumulation in macrophages ensues from the receptor-mediated uptake of $\beta$-VLDL with subsequent lysosomal degradation of the lipoprotein and reesterification of the liberated free cholesterol $[6,18]$. In this series of intracellular events, the current results add the suppressive effect of apo-B-carrying lipoproteins on lysosomal hydrolysis to the contributory factors for an inefficient removal of $\beta$-VLDL. Consequently, overwhelming plasma E-CHO enforces the uptake of $\beta$-VLDL until the cells accumulate a sufficient level of a free cholesterol pool to stimulate E-CHO synthesis. The present findings suggest that the $\beta$-VLDL, the predominant lipoprotein in plasma containing cholesterol exceeding a certain level, accelerates hypercholesterolemia and causes an accumulation of oleate-rich E-CHO in cells with both LDL and $\beta$-VLDL receptors and that this occurs as a result of the combined effects of suppression of lysosomal hydrolysis and stimulation of microsomal synthesis of E-CHO.

\section{REFERENCES}

1. Goldstein, J.L., and Brown, M.S. (1977): The low-density lipoprotein pathway and its relation to atherosclerosis. Ann. Rev. Biochem., 46, 897-930.

2. Maehira, F., Nakada, F., and Hokama, T. (1984): Characteristics of acid esterase in Wolman's disease. Biochem. Med., 32, 322-330.

3. Goldstein, J.L., Dana, S.E., Faust, J.R., Beaudet, A.L., and Brown, M.S. (1975): Role of lysosomal acid lipase in the metabolism of plasma low density lipoprotein. J. Biol. Chem., 250, 8487-8495.

4. Brown, M.S., Ho, Y.K., and Goldstein, J.L. (1980): The cholesteryl ester cycle in macrophage foam cells. J. Biol. Chem., 255, 9344-9352.

5. Ho, Y.K., Faust, J.R., Bilheimer, D.W., Brown, M.S., and Goldstein, J.L. (1977): Regulation of cholesterol synthesis by low density lipoprotein in isolated human lymphocytes. J. Exp. Med., 145, 1531-1549.

6. Mahley, R.W., Linnerarity, T.L., Brown, M.S., Ho, Y.K., and Goldstein, J.L. (1980): Cholesteryl ester synthesis in macrophages: Stimulation by $\beta$-very low density lipoproteins from cholesterol-fed animals of several species. J. Lipid Res., 21, 970-980.

7. Van Lenten, B.J., Fogelman, A.M., Hokom, M.M., Benson, L., Haberland, M.E., and Edwards, P.A. (1983): Regulation of uptake and degradation of $\beta$-very low density lipoprotein in human monocyte macrophages. J. Biol. Chem., 258, 5151-5157.

8. Böyum, A. (1977): Separation of lymphocytes, lymphocyte subgroups and monocytes: A review. Lymphology, 10, 71-77.

9. Stokke, K.T. (1972): The existence of an acid cholesterol esterase in human liver. Biochim. Biophys. Acta, 270, 156-166.

10. Belfrage, P., and Vaughan, M. (1969): Simple liquid-liquid partition system for isolation of labeled oleic acid from mixtures with glycerides. J. Lipid Res., 10, 341-344.

11. Aviram, M. (1983): Plasma lipoprotein separation by discontinuous density gradient ultracentrifugation in hyperlipoproteinemic patients. Biochem. Med., 30, 111-118.

12. Kohn, J. (1961): A lipoprotein staining method for zone electrophoresis. Nature, 189, 312 313.

13. Maehira, F., and Takaesu, I. (1987): Dot immunodetection for sphingomyelinase with monoclonal antibody. Biochem. Med. Metabol. Biol., 37, 5-15.

14. Ouchterlony, Ö. (1968): Handbook of Immunodiffusion and Immunoelectrophoresis, Ann Arbor Science Publishers, Inc., Mich., pp. 21-48.

15. Yagi, K. (1976): A simple fluorometric assay for lipoperoxide in blood plasma. Biochem. 
Med., 15, 212-216.

16. Lowry, O.H., Rosebrough, N.J., Farr, A.L., and Randall, R.J. (1951): Protein measurement with the Folin phenol reagent. J. Biol. Chem., 183, 265-275.

17. Scanu, A.M., and Wisdom, C. (1972): Serum lipoproteins structure and function. Ann. Rev. Biochem., 41, 703-730.

18. Kovanen, P.T., Brown, M.S., Basu, S.K., Bilheimer, D.W., and Goldstein, J.L. (1981): Saturation and suppression of hepatic lipoprotein receptors: A mechanism for the hypercholesterolemia of cholesterol-fed rabbits. Proc. Natl. Acad. Sci. U.S.A., 78, 1396-1400.

19. Rindler-Ludwig, R., Patsch, W., Sailer, S., and Braunsteiner, H. (1977): Characterization and partial purification of acid lipase from human leucocytes. Biochim. Biophys. Acta, $\mathbf{4 8 8}$, 294-304.

20. Brown, W.J., and Sgoutas, D.S. (1980): Purification of rat liver lysosomal cholesteryl ester hydrolase. Biochim. Biophys. Acta, 617, 305-317.

21. Takano, T., and Sato, M. (1977): Enhancement of oleate-rich cholesteryl ester after removal of cholesterol diet from cholesterol-fed rabbits. Chem. Pharm. Bull., 25, 2669-2675. 